\title{
DAMPAK SISTEM PENGENDALIAN INTERNAL, PRILAKU TIDAK ETIS, DAN MORALITAS MANAJEMEN TERHADAP KECENDERUNGAN KECURANGAN AKUNTANSI PADA PERUSAHAAN DEVELOPER DI PEKANBARU
}

\author{
Febri Rahmi \\ Fakultas Ekonomi dan Sosial UIN Sultan Syarif Kasim Riau - Pekanbaru \\ E-mail: febrirahmi@uin-suska.ac.id \\ Asni Sovia \\ Fakultas Ekonomi dan Sosial UIN Sultan Syarif Kasim Riau - Pekanbaru \\ E-mail: asnisovia@uin-suska.ac.id
}

\begin{abstract}
Abstrak
Penelitian ini bertujuan untuk mengetahui dampak penerapan sistem pengendalian internal, perilaku tidak etis dan moralitas manajemen terhadap kecenderungan kecurangan akuntansi. Sampel penelitian ini adalah staf akuntansi. pada perusahaan developer di Pekanbaru. Teknik sampel adalah dengan purposive sampling. Teknik pengumpulan data adalah kuesioner. Analisis data dengan menggunakan regresi linear berganda.

Berdasarkan analisis statistik secara parsial menemukan: 1) hipotesis pertama, kedua dan ketiga diterima (sig 0,006, sig 0,004, sig 0,000) yaitu sistem pengendalian internal, perilaku tidak etis dan moralitas manajemen berpengaruh signifikan terhadap kecenderungan kecurangan akuntansi. Besarnya pengaruh sistem pengendalian internal, perilaku tidak etis dan moralitas manajemen terhadap kecenderungan kecurangan akuntansi sebesar 51\%, sisanya 49\% dipengaruhi oleh variabel lain.
\end{abstract}

Kata Kunci: Pengaruh Sistem Pengendalian Internal, Perilaku Tidak Etis, Moralitas Manajemen, Kecenderungan Kecurangan Akuntansi

\section{PENDAHULUAN}

Kasus

Kecenderungan

Kecurangan Akuntansi (KKA) di Indonesia terjadi secara berulang ulang. Media massa banyak memberitakan hal tersebut sehingga bagi masyarakat kasus KKA sepertinya bukan rahasia lagi. Pada sektor publik, KKA dilakukan dalam bentuk kebocoran Anggaran Pendapatan dan Belanja Negara (APBN). Di sektor swasta bentuk KKA juga terjadi dalam bentuk yang sama yaitu ketidaktepatan dalam membelanjakan sumber dana.

Ketidaktepatan dalam membelanjakan sumber dana membuat organisasi atau lembaga yang dikelola menjadi rugi. Sebagai contoh, volume produktivitas organisasi melemah, belanja sosial organisasi semakin sedikit, kepercayaan masyarakat yang dilayani beralih ke organisasi lain, dan mitra kerja tidak selera lagi untuk tetap bekerja sama. Jika demikian yang terjadi, reputasi dan 
citra organisasi yang terbangun selama ini menjadi sulit untuk dijadikan daya saing dalam meraih persaingan pasar yang semakin tajam.

Persaingan pasar yang semakin tajam seiring dengan perkembangan ekonomi saat ini yang merupakan hasil dari proses pembangunan telah membuat dunia usaha semakin semarak, kompleks, variatif, dan dinamis. Demi kelangsungan hidup perusahaan, setiap perusahaan berusaha untuk menggali segala potensi yang ada agar tetap bertahan dan memenuhi kebutuhan pelanggannya. Perusahaan perlu mengadakan pemeriksaan internal yang memadai serta pengawasan terhadap proses kegiatan perusahaan yang berjalan sesuai prosedur yang telah ditentukan. Tujuannya adalah agar perusahaan dapat meningkatkan atau mencapai kinerja yang diinginkan dan terhindar dari kasus korupsi .

Kasus korupsi terbanyak yang terjadi sepanjang tahun 2014 di Indonesia menurut Indonesia Corruption Watch (2014) adalah Pejabat atau Pegawai Pemda/Kementerian. Khusus semester II 2014, urutan terbanyak tersangka korupsi adalah Pelaksana Proyek (PP), Pejabat Pelaksana Teknis Kegiatan (PPTK), Kuasa Pengguna Anggaran (KPA), dan Pejabat Pembuat Komitmen(PPK). Sementara pada semester I 2014, urutan terbanyak kedua adalah direktur, komisaris, konsultan, dan pegawai swasta.

Menurut Pradnyani (2014) bukti dari kecurangan akuntansi yang terjadi di Indonesia diantaranya adalah adanya likuidasi beberapa bank, penggelapan terhadap penerimaan kas, pencurian aset perusahaan, manipulasi pajak, transaksi tidak resmi, korupsi di komisi penyelenggara pemilu dan lain sebagainya. Kerugian dari kecurangan akuntansi salah satunya adalah menurunnya akuntabilitas manajemen yang membuat para pemegang saham meningkatkan biaya monitoring terhadap manajemen.

Pengendalian internal yang efektif dapat memberikan manfaat yang besar bagi perusahaan dan dapat mempercepat proses kegiatan yang sedang berlangsung di perusahaan. Sistem Pengendalian Internal juga merupakan faktor yang mempengaruhi adanya kecenderungan kecurangan akuntansi. Pengendalian internal memegang peran penting dalam organisasi untuk meminimalisir terjadinya kecurangan. Pengendalian internal yang efektif akan menutup peluang terjadinya perilaku yang tidak etis. (Toyibatun, 2009)

Perilaku tidak etis muncul karena karyawan merasa tidak puas dan kecewa dengan hasil yang di dapat dari perusahaan serta lemahnya pengawasan manajemen yang dapat membuka keleluasaan karyawan untuk melakukan tindakan yang dapat merugikan perusahaan. Perusahaan dituntut untuk mampu mendorong terbentuknya perilaku etis pada karyawannya dalam meminimalisir tendensi terjadinya kecurangan akuntansi (Adelin, 2009).

Berita yang ditulis oleh liputan 6 SCTV (12 juli 2015) dimana ratusan masa buruh dan karyawan berdemo di depan Mahkamah Agung 
tentang tuntutan kenaikan gaji dan penghapusan sistem kerja outsourching. Buruh dan karyawan menuntut kenaikan upah gaji dan kenaikan tunjangan kesehatan serta pensiun. Gaji dan upah merupakan kompensasi yang diberikan perusahaan kepada buruh karyawan, ketika hasil yang diperoleh mereka bertentangan dengan kebutuhan buruh dan karyawan. Tindakan yang dilakukan oleh perusahaan disebabkan oleh salah satu dari adanya tindakan perilaku tidak etis dan kecurangan akuntansi.

Kasus kecurangan di Indonesia yang perlu menjadi perhatian salah satunya terjadi pada sektor properti dan REI (Real Estate Indonesia). Hal tersebut dikarenakan semakin banyaknya pengembang proyek yang membangun berbagai macam hunian seperti, perumahan, kawasan apartemen dan lain sebagainya. Semakin berkembangnya suatu sektor, seperti sektor properti dan real estate mendorong adanya kemungkinan terjadi kecenderungan kecurangan (fraud).

Menurut Sudaryatmo (ketua Yayasan Lembaga Konsumen Indonesia) telah terjadi peningkatan pada pengaduan kasus hukum sektor properti oleh konsumen ke Yayasan tersebut. Kasus pada sektor ini berada diurutan kedua setelah sektor keuangan dan perbankan (Tribun Timur, 2015). Berdasarkan data Yayasan Lembaga Konsumen Indonesia terdapat 157 kasus pengaduan sektor properti yang ditujukan kepada sekitar 100 pengembang. Dari keseluruhan kasus terdapat 17 jenis keluhan, seperti pengembang ingkar janji, keterlambatan serah terima unit bangunan, keterlambatan serah terima sertifikat, pengembalian dana yang tidak segera diselesaikan, ketersediaan fasilitas khusus dan umum, perbedaan kualitas, spesifikasi, dan desain tata letak bangunan, perjanjian pengikatan jual beli, akta jual beli dan hak guna bangunan, iuran pengelola lingkungan, penjadwalan ulang cicilan, tanah properti yang dijual mengalami sengketa, perbedaan luas selisih bangunan, promo brosur yang tidak sesuai, keanggotaan Perhimpunan Pemilik dan Penghuni Satuan Rumah Susun, pelayanan yang tidak memuaskan, dan keluhan lainnya (kompas.com, 2015). Peningkatan kasus pada sektor ini sebesar $12,7 \%$ dari tahun 2013 yang hanya 121 kasus, mengindikasi perlunya sistem pengendalian yang efektif dan pengawasan terhadap potensi kecurangan di sektor ini.

Efendi (2010) melakukan penelitian pada Perusahaan Developer di Pekanbaru menemukan adanya kecurangan yang dilakukan oleh para penjual maupun pembeli properti guna mengecilkan atau menghapus pajak yang harus dibayar. Kecurangan ini terjadi karena adanya penjualan properti dengan harga diskon ke broker properti tanpa akta peralihan hak, hanya kuasa menjual. Transaksi yang terjadi membuat penjual maupun pembeli tidak terkena pajak, walaupun sudah ada pembayaran dari broker kepada developer.

Beberapa penelitian menunjukkan faktor-faktor yang mempengaruhi kecenderungan kecurangan (fraud). Penelitian Efendi (2010) menunjukkan Pengendalian Internal, Ketaatan 
aturan akuntansi, asimetri informasi dan kesesuaian kompensasi berpengaruh positif terhadap terjadinya kecenderungan

kecurangan Akuntansi. Penelitian Toyibatun (2009) menunjukan bahwa kesesuaian sistem pengendalian internal, sistem kompensasi, ketaatan terhadap aturan, dan perilaku tidak etis berpengaruh positif terhadap terjadinya kecenderungan kecurangan Akuntansi. Penelitian Satyawati (2014) menunjukan sistem pengendalian internal, moralitas manajemen kesesuaian kompensasi memiliki pengaruh negatif terhadap kecenderungan kecurangan akuntansi.

Penelitian ini mengacu pada penelitian Efendi (2010) dan Toyibatun (2009). Variabel dalam Penelitian ini adalah sistem pengendalian internal, perilaku tidak etis dan kecenderungan kecurangan akuntansi. Tambahan variabel penelitian ini adalah moralitas manajemen, karena moral manajemen dapat mempengaruhi kualitas laporan yang dihasilkannya terutama berkaitan dengan akuntansi

Berdasarkan fenomena dan hasil penelitian yang kontradiktif memotivasi untuk dilakukan penelitian kembali tentang kecenderungan kecurangan akuntansi. Penelian pada perusahaan Developer di Pekanbaru juga pernah dilakukan oleh Efendi (2010), perbedaannya adalah : pertama, variabel yang digunakan oleh Efendi terdiri dari pengendalian internal, ketaatan aturan akuntansi, asimetri informasi, kesesuaian kompensasi dan kecenderungan kecurangan Akuntansi. Sementar dalam penelitian ini menggunakan variable system pengendalian internal, prilaku tidak etis, moralitas manajemen dan kecenderungan kecurangan Akuntansi. Kedua, objek penelitian pada perusahaan developer yang termasuk dalam program sejuta rumah Real Estate Indonesia (REI).

Adapun judul penelitian ini adalah "Dampak Sistem Pengendalian Internal, Prilaku Tidak Etis, Dan Moralitas Manajemen Terhadap Kecenderungan Kecurangan Akuntansi Pada Perusahaan Developer di Pekanbaru."

\section{TINJAUAN PUSTAKA}

\section{Teori Atribusi}

Teori Atribusi (Atribution

Theory) merupakan teori dari Harold Kelley (1972-1973) dalam teorinya menjelaskan tentang bagaimana orang menarik kesimpulan tentang "apa yang menjadi sebab" apa yang menjadi dasar seseorang melakukan suatu perbuatan atau memutuskan untuk berbuat dengan cara-cara tertentu. Ada tiga faktor yang menjadi tiga factor yang menjadi dasar pertimbangan orang untuk menarik kesimpulan apakah suatu tindakan atau perbuatan disebabkan oleh sifat dari dalam diri (disposisi) ataukah disebabkan oleh faktor di luar diri. Ketiga faktor dasar pertimbangan tersebut adalah: 1 . Konsensus (Concensus), 2. Konsisten (Consistency) 3. Keunikan (Distinctivens)

Teori Atribusi menurut Ikhsan dan Ishak (2005) merupakan suatu proses untuk menginterpretasikan suatu 
peristiwa, alasan, atau sebab perilaku seseorang. Teori ini ingin menjelaskan tentang perilaku seseorang terhadap peristiwa di sekitarnya dan mengetahui alasanalasan melakukan perilaku seperti itu. Teori Atribusi yang dikemukakan oleh Robbins (2006) menjelaskan perilaku seseorang yang disebabkan oleh faktor internal atau faktor eksternal. Jadi dapat disimpulkan bahwa Teori Atribusi adalah teori yang menjelaskan upaya untuk memahami penyebab dibalik perilaku orang lain.

Perilaku ini disebabkan oleh faktor internal dan faktor eksternal. Perilaku yang disebabkan oleh faktor internal adalah perilaku yang diyakini berada di bawah kendali atau berasal dari dalam diri individu seperti ciri kepribadian, motivasi atau kemampuan. Perilaku yang disebabkan oleh faktor eksternal adalah perilaku yang diyakini sebagai hasil dari sebab-sebab luar atau berasal dari luar diri individu seperti peralatan atau pengaruh sosial dari orang lain (Kusumastuti, 2012).

\section{Teori Perkembangan Moral}

Lawrence Kohlberg Oktober 1927 - 19 Januari 1987) adalah seorang psikolog Amerika terkenal karena teorinya tentang tahapan perkembangan moral. Ia menjabat sebagai profesor di Departemen Psikologi di University of Chicago dan di Graduate School of Education di Harvard University (Nusantara, 2016).

Tahapan perkembangan moral adalah ukuran dari tinggi rendahnya moral seseorang berdasarkan perkembangan penalaran moralnya. Tahapan perkembangan moral terbagi menjadi tiga tahapan yaitu prekonvensional, konvensional, dan post-konvensional. Dalam tahapan yang paling rendah (preconventional), individu akan melakukan suatu tindakan karena takut terhadap hukum/peraturan yang ada. Selain itu individu pada level moral ini juga akan memandang kepentingan pribadinya sebagai hal yang utama dalam melakukan suatu tindakan. Pada tahap kedua (conventional), individu akan mendasarkan tindakannya persetujuan teman-teman dan keluarganya dan juga pada normanorma yang ada di masyarakat. Pada tahap ke tiga perkembangan moral adalah ukuran dari tinggi rendahnya moral seseorang.

Manajemen pada tahapan post konvensional menunjukkan kematangan moral manajemen yang tinggi. Kematangan moral menjadi dasar dan pertimbangan manajemen dalam merancang tanggapan dan sikap terhadap isuisu etis. Perkembangan pengetahuan moral menjadi indikasi pembuatan keputusan yang secara etis serta positif berkaitan dengan perilaku pertanggung jawaban sosial. Karena adanya tanggung jawab sosial, manajemen dengan moralitas yang tinggi diharapkan tidak melakukan perilaku menyimpang dan kecurangan dalam kinerjanya. Moralitas manajemen yang tinggi diharapkan akan menurunkan 
perilaku tidak etis dan kecurangan akuntansi yang dilakukan manajemen perusahaan. Namun sebaliknya jika yang terjadi adalah manajemen dengan moralitas yang rendah akan memicu terjadinya perilaku menyimpang dan kecurangan dalam kinerjanya. Termasuk adanya perilaku tidak etis dari manajemen dan kecurangan akuntansi. Moralitas manajemen yang rendah dapat meningkatkan perilaku tidak etis dan kecurangan akuntansi yang dilakukan manajemen perusahaan.

3. Sistem Pengendalian internal dan kecenderungan kecurangan akuntansi

Menurut Frilia (2015) dalam penelitiannya menunjukan bahwa sistem pengendalian internal berpengaruh signifikan terhadap kecenderungan kecurangan akuntansi. Pada dasarnya kecurangan terjadi karena adanya kesempatan, semakin besar peluang kesempatan untuk melakukan kecurangan maka semakin sering pula kecurangan yang akan terjadi. Lemahnya pengendalian internal akan membukakan pintu untuk melakukan kecurangan. Sistem pengendalian intern yang lemah, membuat seseorang tidak takut untuk melakukan tindakan yang merugikan perusahaan, karena tindakan yang mereka lakukan tidak terdeteksi oleh siapapun dan sebaliknya.

Adelin (2009) dalam penelitiannya menunjukkan bahwa sistem pengendalian internal berpengaruh negatif terhadap kecenderungan kecurangan akuntansi. Hal ini dikarenakan pengendalian internal yang efektif memungkinkan terjadinya pengecekan saling silang (cross check) terhadap pekerjaan seseorang oleh orang lain. Hal ini menurunkan peluang terjadinya kecenderungan kecurangan. Efendi (2010) menyatakan bahwa salah satu upaya untuk meminimalisir tindakan kecurangan adalah dengan meningkatan sistem pengendalian internal yang efektif, sehingga terdapat pengaruh positif antara pengendalian internal terhadap kecenderungan kecurangan akuntansi. Bardasarkan hal di atas maka hipotesis penelitian ini sebagai berikut

$$
\begin{aligned}
& \text { H1 : Sistem Pengendalian } \\
& \text { Internal berpengaruh } \\
& \text { signifikan terhadap } \\
& \text { kecenderungan kecurangan } \\
& \text { akuntansi. }
\end{aligned}
$$

\section{Perilaku tidak etis dan kecenderungan kecurangan akuntansi}

Griffin dan Ebert (2007:58) menyatakan bahwa perilaku tidak etis adalah perilaku yang tidak sesuai dengan norma-norma sosial yang diterima secara umum, sehubungan dengan tindakan yang bermanfat atau yang membahayakan. Prinsip tersebut menunjukkan sikap dari manajemen dalam mengelola perusahaan. Prinsip tersebut mewakili sikap manajemen dalam mengelola suatu perusahaan atau instansi. Jika perilaku yang ditunjukkan manajemen cenderung tidak etis maka 
kecenderungan kecurangan akuntansi akan semakin tinggi.

Menurut Adelin (2009) perilaku tidak etis berpengaruh signifikan positif terhadap kecenderungan kecurangan akuntansi, artinya semakin tinggi perilaku tidak etis pada suatu perusahaan, maka semakin tinggi pula kecenderungan kecurangan akuntansi pada perusahaan tersebut. Sustriana (2015) dalam penelitian menunjukkan bahwa perilaku tidak etis berpengaruh signifikan terhadap kecenderungan kecurangan akuntansi. Berdasarkan hal di atas maka hipotesis penelitian sebagai berikut:
H2 : Sikap Tidak Etis berpengaruh signifikan terhadap kecenderungan kecurangan akuntansi.

\section{Moralitas manajemen dan} kecenderungan kecurangan akuntansi

Pradnyani (2014) dalam penelitiannya menunjukan bahwa moralitas manajemen tidak berpengaruh terhadap terjadinya kecenderungan kecurangan akuntansi. Semakin tinggi tahapan moralitas manajemen (tahapan postkonvensional), semakin manajemen memperhatikan kepentingan yang lebih luas dan universal daripada kepentingan perusahaan semata, terlebih kepentingan pribadinya. Oleh karenanya, semakin tinggi moralitas manajemen, semakin manajemen berusaha menghindarkan diri dari kecenderungan kecurangan akuntansi. Rahmawati (2012) menunjukan bahwa moralitas manajemen memiliki pengaruh signifikan terhadap kecenderungan kecurangan akuntansi. jika moralitas manajemen rendah, maka kemungkinan terjadinya kecurangan masih dapat terjadi. Berdasarkan hal di atas maka hipotesis penelitian sebagai berikut:

H3: Moralitas Manajemen berpengaruh signifikan terhadap kecenderungan kecurangan akuntansi.

Kerangka konseptual merupakan gambaran tentang pola hubungan antar variabel-variabel yang diteliti. Berdasarkan penjelasan yang telah diuraikan diatas, kerangka konseptual penelitian ini dapat digambarkan sebagai berikut:

Gambar 2.1

\section{Kerangka Konseptual}

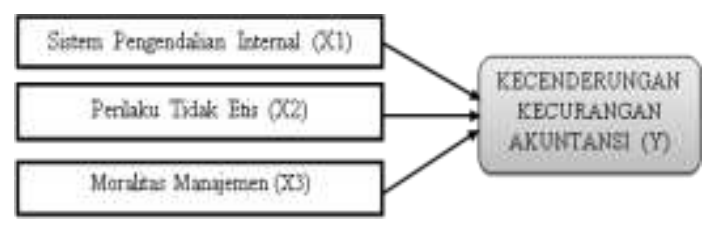

\section{METODE PENELITIAN}

Jenis penelitian ini adalah kuantitatif. populasi dalam penelitian ini yaitu perusahaan developer yang termasuk kedalam Real Estat Indonesia (REI) di kota Pekanbaru yang terdaftar di Dinas Perindustrian dan Perdagangan Kota Pekanbaru pada tahun 2015. Lokasi ini dipilih berdasarkan pertimbangan bahwa daerah ini merupakan daerah berpotensi dalam perkembangan ekonomi di masa yang akan dating. REI menetapkan Pekanbaru sebagai kota terbaik di Indonesia Pekanbaru adalah Kota yang paling mudah, paling murah dan paling cepat dalam 
hal pengurusan izin property di Indonesia, serta adanya kebijakan memberi kemudahan bagi pengembang yang membangun perumahan di Pekanbaru. Sampel

1. Perusahaan termasuk kedalam Real Estat Indonesia (REI)

2. Terdaftar di Dinas Perindustrian dan Perdagangan Provinsi Riau

3. Perusahaan telah berjalan lebih dari 5 tahun berlokasi di Pekanbaru

Teknik pengumpulan data dalam penelitian ini adalah dengan kuesioner terutama pada staf penelitian adalah perusahaan developer yang termasuk dalam program sejuta rumah Real Estate Indonesia (REI), dengankriteria sebagai berikut:

keuangan yang ada di perusahaan developer. Variabel penelitian ini terdiri dari 3 variable independen yaitu: Sistem Pengendalian Internal (SPI), perilaku tidak etis, moralitas manajemen dan varabel dependen yaitu kecenderungan kecurangan akutansi. Indikator dari setiap variable adalah:

Tabel 3.1.

Definisi dan Indikator Variabel Penelitian

\begin{tabular}{|c|c|}
\hline Variabel dan Konsep & Indikator \\
\hline $\begin{array}{l}\text { Pengendalian Internal (X1) } \\
\text { Sistem pengendalian internal merupakan suatu } \\
\text { perencanaan yang meliputi struktur organisasi } \\
\text { dan semua metode dan alat-alat yang } \\
\text { dikoordinasikan dan digunakan didalam } \\
\text { perusahaan dengan tujuan untuk menjaga } \\
\text { keamanan hak milik perusahaan, memeriksa } \\
\text { ketelitian dan kebenaran data akuntansi, } \\
\text { mendorong efisiensi, dan membantu } \\
\text { mendorong dipatuhinya kebijakan manajemen } \\
\text { yang telah ditetapkan. (Raharjo, 2015). }\end{array}$ & $\begin{array}{l}\text { 1. Penerapan wewenang dan } \\
\text { tanggung } \\
\text { jawab. } \\
\text { 2. Pencatatan transaksi } \\
\text { 3. Aktivitas pengendalian } \\
\text { 4. Informasi dan komunikasi } \\
\text { 5. Pemantauan dan evaluasi }\end{array}$ \\
\hline $\begin{array}{l}\text { Prilaku Tidak Etis (X2) } \\
\text { Perilaku tidak etis merupakan perilaku yang } \\
\text { menyalahgunakan jabatan, sumber daya } \\
\text { organisasi, kekuasaan, dan perilaku yang tidak } \\
\text { berbuat apa apa sehubungan dengan jabatan } \\
\text { dan kekuasaannya. (mustika,2016) }\end{array}$ & $\begin{array}{l}\text { 1. Menggunakan kendaraan } \\
\text { dinas untuk keperluan } \\
\text { pribadi } \\
\text { 2. Perilaku manajemen yang } \\
\text { menyalahkan sumber daya } \\
\text { organisasi } \\
\text { 3. Perilaku manajemen yang } \\
\text { menyalahkan kekuasaan } \\
\text { 4. Perilaku manajemen yang } \\
\text { tidak berbuat apa-apa } \\
\text { 5. Perilaku manajemen yang } \\
\text { mengabaikan peraturan }\end{array}$ \\
\hline $\begin{array}{l}\text { Kesesuaian Kompensasi }(\mathbf{X 3}) \\
\text { Kesesuaian kompensasi didefinisikan sebagai } \\
\text { keseluruhan balas jasa yang diterima oleh } \\
\text { pegawai sebagai akibat dari pelaksanaan di }\end{array}$ & $\begin{array}{lr}\text { 1. Kompensasi } & \text { keuangan } \\
\text { sesuai dengan } & \text { prestasi } \\
\text { karyawan } & \\
\text { 2. Kompensasi } & \text { diberikan } \\
\end{array}$ \\
\hline
\end{tabular}


organisasi dalam bentuk uang atau lainnya, yang dapat berupa gaji, upah, bonus, insentif, dan tunjangan lainnya. (Hariandja, 2002)

\section{Moralitas Manajemen (X4)}

Kematangan moral manajemen menjadi indikasi pembuatan keputusan yang secara etis serta positif berkaitan dengan perilaku pertanggung-jawaban sosial. Adanya tanggung jawab sosial diharapkan membuat manajemen bertindak lebih baik dan tidak melakukan penyimpangan-penyimpangan. Manajemen dengan moralitas yang tinggi diharapkan tidak melakukan tindakan-tindakan yang tidak etis dan melakukan kecurangan akuntansi untuk memaksimalkan keuntungan pribadi. (Fawzi, 2011)

Kecenderungan Kecurangan Akuntansi (Y) Kecurangan akuntansi sebagai: (1) Salah saji yang timbul dari kecurangan dalam pelaporan keuangan yaitu salah saji atau penghilangan secara sengaja jumlah atau pengungkapan dalam laporan keuangan untuk mengelabuhi pemakai laporan keuangan.

(2) Salah saji yang timbul dari perlakuan tidak semestinya terhadap aset (seringkali disebut dengan penyalahgunaan atau penggelapan) berkaitan dengan pencurian aset entitas yang berakibat laporan keuangan tidak disajikan karna karyawan menguasai dan bertanggung jawab atas pekerjaan

3. Promosi diberikan atas dasar prestasi kerja karyawan

4. Penyelesaian tugas dengan baik

5. Pencapaian pekerjaan dalam waktu tertentu

6. Kompensasi berdasarkan kemampuan pengetahuan dan keahlian dibidangnya

1. Rekayasa laporan keuangan untuk pertahankan pemegang saham

2. Rekayasa laporan keuangan untuk memperoleh bonus

3. Rekayasa laporan keuangan untuk memperlihatkan kinerja perusahaan agar terlihat baik

4. Kelaziman rekayasa laporan keuangan setiap periode

5. Rekayasa laporan keuangan karna tidak akan merugikan perusahaan dan tidak terkena sanksi

6. Pertimbangan direksi membua laporan keuangan yang sebenarnya terkait untuk kepentingan perusahaan dan kesejahteraan karyawan

1. Perkecil biaya agar laba besar.

2. Tidak mencatat dokumen penyuapan kepada pejabat pemerintah

3. Perkecil cadangan piutang macet agar laba besar.

4. Tidak menerima pembayaran fiktif.

5. Menolak permintaan komisaris utama untuk beli rumah perusahaan dengan 
dengan benar. (IAPI, 2013)

harga murah (di bawah

harga pasar).

Metode analisis dalam penelitian ini adalah analisis statistik deskriptif, analisis kualitas data dan analisis hipotesis. Analisis statistik deskriptip untuk mendapatkan informasi mengenai data. Kualitas data diuji dengan uji validitas dan reliabilitas serta uji normalitas data. Analisis hipotesis dalam penelitian ini menggunakan analisis regresi linier berganda. Persamaan penelitian ini sebagai berikut:

$$
\mathbf{Y}=\alpha+\beta_{1} X_{1}+\beta_{2} X_{2}+\beta_{3} X_{3}+\mu
$$

Keterangan :

$\begin{array}{lll}\mathrm{Y} & = & \text { kecenderungan kecurangan akuntansi } \\ \alpha & = & \text { Konstanta } \\ \beta(1234) & = & \text { Koefisien Regresi } \\ \mathrm{X}_{1} & = & \text { sistem pengendalian internal } \\ \mathrm{X}_{2} & = & \text { prilaku tidak etis } \\ \mathrm{X}_{3} & = & \text { moralitas manajemen } \\ \mu & = & \text { Error }\end{array}$

\section{HASIL DAN PEMBAHASAN}

\section{Statistik Deskriptif}

Penelitian ini dilakukan pada Perusahaan Developer yang berada di Pekanbaru. Penelitian ini dilakukan untuk mengetahui faktorfaktor yang mempengaruhi kecenderungan kecurangan akuntansi. Perusahaan Developer merupakan suatu perusahaan yang bergerak dalam bidang pembangunan perumahan dari berbagai jenis dalam jumlah yang besar di atas suatu kesatuan lingkungan pemukiman yang dilengkapi dengan prasaranaprasarana lingkungan dan fasilitas sosial yang diperlukan oleh masyarakat penghuninya.

Tabel 1

Descriptive Statistics

\begin{tabular}{|l|c|c|c|c|c|}
\hline \multicolumn{1}{|c|}{ Variabel } & N & Minimum & Maximum & Mean & $\begin{array}{c}\text { Std. } \\
\text { Devia } \\
\text { tion }\end{array}$ \\
\hline Sistem Pengendalian Internal (X1) & 30 & 8 & 18 & 11,67 & 2,746 \\
Perilaku Tidak Etis (X2) & 30 & 5 & 12 & 8,87 & 2,224 \\
Kesesuaian Kompensasi (X3) & 30 & 20 & 29 & 23,67 & 2,758 \\
Moralitas Manajemen (X4) & 30 & 7 & 22 & 14,67 & 4,188 \\
Kecenderungan Kecurangan & 30 & 13 & 22 & 16,17 & 2,653 \\
Akuntansi (Y) & 30 & & & & \\
Valid N (listwise) & & & & & \\
\hline
\end{tabular}

Sumber: Data olahan SPSS 2016 
Berdasarkan tabel 1, jawaban yang diberikan responden terhadap variabel X1 (sistem pengendalian internal) memiliki nilai minimum 8 , nilai maksimum 18 , nilai rata-rata sebesar 11,67 dan nilai standar deviasi 2,746. Jawaban yang diberikan responden terhadap variabel X2 (prilaku tidak etis) menunjukkan nilai minimum sebesar 5 , nilai maximum sebesar 12 , nilai rata-rata sebesar 8,87 dan nilai standar deviasi 2,224. Jawaban yang diberikan responden terhadap variabel X4 (moralitas manajemen) menunjukkan nilai minimum sebesar 7 , nilai maximum sebesar 22 , nilai rata-rata sebesar 14,67 dan nilai standar deviasi 4,188. Jawaban yang diberikan responden terhadap variabel Y (kecenderungan kecurangan akuntansi) memiliki nilai minimum sebesar 13, nilai maximum sebesar 22, nilai rata-rata sebesar 16,17 dan nilai standar devisiasi sebesar 2,653.

Semua variabel dapat terpenuhi uji validitas dan uji reliabilitas sebagai berikut:

Tabel 2

Hasil Pengujian Validitas dan Reliabilitas

\begin{tabular}{|l|c|c|c|c|}
\hline \multicolumn{1}{|c|}{ Variabel } & Validitas & $\begin{array}{c}\text { Nilai } \\
\text { Cronbach's } \\
\text { Alpha }\end{array}$ & $\begin{array}{c}\text { Nilai } \\
\text { Kritis }\end{array}$ & $\begin{array}{c}\text { Kesimpul } \\
\text { an }\end{array}$ \\
\hline Sistem Pengendalian Internal & valid & 0,835 & 0,60 & Reliabel \\
\hline Prilaku Tidak Etis & valid & 0,818 & 0,60 & Reliabel \\
\hline Moralitas Manajemen & valid & 0,845 & 0,60 & Reliabel \\
\hline $\begin{array}{l}\text { Kecenderungan Kecurangan } \\
\text { Akuntansi }\end{array}$ & valid & 0,770 & 0,60 & Reliabel \\
\hline
\end{tabular}

Sumber: Data olahan SPSS 2016

Hasil uji normalitas dengan menggunakan uji KolmogorovSmirnov pada tabel 4.3 diatas dapat dilihat bahwa nilai Asymp.Sig (2tailed) sebesar 0,996 >0,05. Dengan

demikian, dapat disimpulkan bahwa model regresi memenuhi asumsi normalitas, yaitu data terdistribusi secara normal.

Tabel 3

Uji Normalitas One-Sample Kolmogorov Test

\begin{tabular}{|ll|r|}
\hline & & $\begin{array}{c}\text { Unstandardized } \\
\text { Residual }\end{array}$ \\
\hline Normal Parameters & aean & 30 \\
& Std. Deviation &, 0000000 \\
Most Extreme Differences & Absolute & 1,75879930 \\
& Positive &, 075 \\
Kolmogorov-Smirnov Z & Negative &, 060 \\
Asymp. Sig. (2-tailed) & &,- 075 \\
& &, 411 \\
\hline
\end{tabular}

a. Test distribution is Normal. 
Berdasarkan hasil analisis regresi linier berganda pada tabel 4.3, dimana nilai t tabel pada taraf signifikansi $5 \%$ dapat diketahui sebagai berikut: nilai t tabel dengan jumlah sampel $(\mathrm{n})=30$, jumlah variabel $(\mathrm{k})=4$, taraf signifikansi $\alpha=$ $5 \%$ atau 0,05 , dan degree of freedom $(\mathrm{df})=\mathrm{n}-\mathrm{k}-1=30-4-1=25, \mathrm{t}$ tabel adalah 2,060.

Tabel 4

Hasil Analisis Regresi Linier Berganda Coefficients $^{\mathrm{a}}$

\begin{tabular}{|c|c|c|c|c|c|}
\hline \multirow[b]{2}{*}{ Model } & \multicolumn{2}{|c|}{$\begin{array}{l}\text { Unstandardized } \\
\text { Coefficients }\end{array}$} & \multirow{2}{*}{$\begin{array}{c}\begin{array}{c}\text { Standardized } \\
\text { Coefficients }\end{array} \\
\text { Beta }\end{array}$} & \multirow[b]{2}{*}{$\mathrm{T}$} & \multirow[b]{2}{*}{ Sig. } \\
\hline & $\mathrm{B}$ & Std. Error & & & \\
\hline 1 (Constant) & 1.848 & 2.664 & & .694 & .494 \\
\hline $\begin{array}{l}\text { Sistem Pengendalian } \\
\text { Interen }\end{array}$ & .395 & .131 & .408 & 3.020 & .006 \\
\hline Perilaku Tidak Etis & .509 & .163 & .427 & 3.128 & .004 \\
\hline Moralitas manajemen & .355 & .086 & .560 & 4.134 & .000 \\
\hline
\end{tabular}

a. Dependent Variable: Kecendrungan Kecurangan Akuntansi

Sumber: Data olahan SPSS, 2016

Berdasarkan output diatas, pengujian hipotesis dalam penelitian ini dapat dijabarkan sebagai berikut dengan nilai $\mathrm{t}$ tabel pada taraf signifikansi $5 \%$ dan df (derajat kebebasan) atau $\mathrm{t}$ tabel n-k-1 $=25$ adalah 2.060:

a. Sistem pengendalian internal berpengaruh terhadap

kecenderungan kecurangan akuntansi.

Sistem pengendalian internal diketahui thitung (3.020) $>\mathrm{t}$ tabel (2.060) dan sig $(0,006)<0,05$. Artinya variabel sistem pengendalian internal (X1) secara parsial memiliki pengaruh yang signifikan terhadap kecenderungan kecurangan akuntansi, atau dengan kata lain hipotesis (H1) diterima.

b. Perilaku tidak etis berpengaruh terhadap kecenderungan kecurangan akuntansi.

Perilaku tidak etis diketahui $\mathrm{t}$ hitung (3.128) > t tabel (2.060) dan sig $(0,004)<0,05$. Artinya variabel perilaku tidak etis secara parsial memiliki pengaruh yang signifikan terhadap kecenderngan kecurangan akuntansi, atau dengan kata lain hipotesis (H2) diterima.

c. Moralitas manajemen berpengaruh terhadap kecenderungan kecurangan akuntansi.

Moralitas manajemen diketahui $\mathrm{t}$ hitung (4.134) > t tabel (2.060) dan sig $(0,000)<0,05$. Artinya variabel moralitas manajemen secara parsial memiliki pengaruh yang signifikan terhadap kecenderungan kecurangan akuntansi., atau dengan kata lain hipotesis (H3) diterima.

Berdasarkan hasil analisis regresi pada tabel 4.3 diatas dapat dibuat persamaan regresi linier berganda sebagai berikut:

$$
\mathbf{Y}=\alpha++\boldsymbol{\beta}_{1} \mathbf{X}_{1}++\boldsymbol{\beta}_{2} \mathbf{X}_{2}+\boldsymbol{\beta}_{3} \mathbf{X}_{3}+
$$




$$
\begin{gathered}
\mathrm{Y}=1,848+0,395 \mathrm{X} 1+0,509 \mathrm{X} 2+ \\
0,355 \mathrm{X} 3+\boldsymbol{\mu}
\end{gathered}
$$

Berikut penjelasan dari persamaan regresi linier berganda yang terbentuk:

1. Nilai konstanta $(\alpha)$ sebesar 1,848 Artinya, jika variabel independen tetap maka nilai variabel dependen adalah sebesar 1,848.

2. Nilai koefisien regresi variabel Sistem pengendalian internal (X1) adalah sebesar 0,395. Artinya, setiap perubahan 1 satuan variabel Sistem pengendalian internal, maka akan meningkatkan kecenderungan kecurangan akuntansi sebesar 0,395 dengan asumsi variabel lain tetap.

3. Nilai koefisien regresi variabel perilaku tidak etis (X2) adalah sebesar 0,509 Artinya, setiap perubahan 1 satuan variabel perilaku tidak etis, maka akan meningkatkan kecenderungan kecurangan akuntansi sebesar 0,509 dengan asumsi variabel lain tetap.

4. Nilai koefisien regresi variabel moralitas manajemen (3) adalah sebesar 0,355. Artinya, setiap perubahan 1 satuan variabel moralitas manajemen, maka akan meningkatkan kecenderungan kecurangan akuntansi sebesar 0,355 dengan asumsi variabel lain tetap

5. Standar error (e) merupakan variabel acak dan mempunyai distribusi probabilitas. Standar error (e) mewakili semua faktor yang mempunyai pengaruh terhadap $Y$ tetapi tidak dimasukkan dalam persamaan.

Berdasarkan hasil Uji-F dapat dilihat tabel 4.4. sebagai berikut:

Tabel 5

ANOVA $^{\mathrm{a}}$

\begin{tabular}{|rl|r|r|r|r|r|}
\hline \multicolumn{2}{|l|}{ Model } & \multicolumn{1}{|c|}{$\begin{array}{c}\text { Sum of } \\
\text { Squares }\end{array}$} & \multicolumn{1}{c|}{ df } & $\begin{array}{c}\text { Mean } \\
\text { Square }\end{array}$ & \multicolumn{1}{c|}{ F } & Sig. \\
\hline 1 & Regression & 114.220 & 3 & 38.073 & 11.005 & $.000^{\mathrm{b}}$ \\
& Residual & 89.947 & 26 & 3.459 & & \\
& Total & 204.167 & 29 & & & \\
\hline
\end{tabular}

a. Dependent Variable: Kecendrungan Kecurangan Akuntansi

b. Predictors: (Constant), Moralitas manajemen, Sistem Pengendalian Interen, Perilaku Tidak Etis 
Berdasarkan tabel 5 diketahui F hitung sebesar 11,005 dengan signifikansi 0,000. Berikut untuk memperoleh nilai $\mathrm{F}$ hitung adalah:

Df1 (n1=k-1) $\rightarrow \quad(\mathrm{n} 1=4-1=3)$ $\mathrm{Df} 2(\mathrm{n} 2=\mathrm{n}-\mathrm{k}) \rightarrow \quad(\mathrm{n} 2=30-4=26)$

Keterangan :

$\mathrm{n}=$ jumlah sampel,

$\mathrm{k}=$ jumlah semua Variabel probabilitas $\alpha=5 \%$,

maka nilai f tabelnya adalah 2,980 . (Lihat pada $\mathrm{N} 1=3$ dan $\mathrm{N} 2=26$. signifikansi $\mathrm{F}$ lebih kecil dari 5\%)
Diperoleh F hitung $(11,005)>$ F tabel $(2,980)$ dengan Sig $(0,000)<$ 0,05 . Artinya, bahwa semua variabel independen (X) yaitu sistem pengendalian internal $\left(\mathrm{X}_{1}\right)$, perilaku tidak etis $\left(\mathrm{X}_{2}\right)$, moralitas manajemen $\left(\mathrm{X}_{3}\right)$ dalam penelitian ini secara bersama-sama (simultan) berpengaruh signifikan terhadap variabel dependen (Y) yaitu kecenderungan kecurangan akuntansi

Tabel 6

Hasil Uji Koefisien Determinasi Model Summary

\begin{tabular}{|l|c|r|r|r|}
\hline Model & R & R Square & Adjusted R Square & Std. Error of the Estimate \\
\hline 1 & $.748^{\mathrm{a}}$ & .559 & .509 & 1.860 \\
\hline
\end{tabular}

a. Predictors: (Constant), Moralitas manajemen, Sistem Pengendalian Interen,

Perilaku Tidak Etis

Dari hasil tabel 6 di atas dapat dilihat bahwa nilai $\mathrm{R}$ square sebesar 0,559 dan nilai koefisien determinan yang sudah disesuaikan (adjust $r$ square) sebesar 0,509. Berdasarkan hasil koefisien determinasi diperoleh angka $51 \%$ variabel yang diteliti yaitu sistem pengendalian internal, perilaku tidak etis, dan moralitas manajemen secara bersama dapat menjelaskan variabel kecenderungan kecurangan akuntansi dan sisanya sebesar $49 \%(100 \%-51 \%)$ dipengaruhi oleh variabel lain.

\section{Pembahasan}

\section{Sistem Pengendalian Internal dan Kecenderungan Kecurangan Akuntansi}

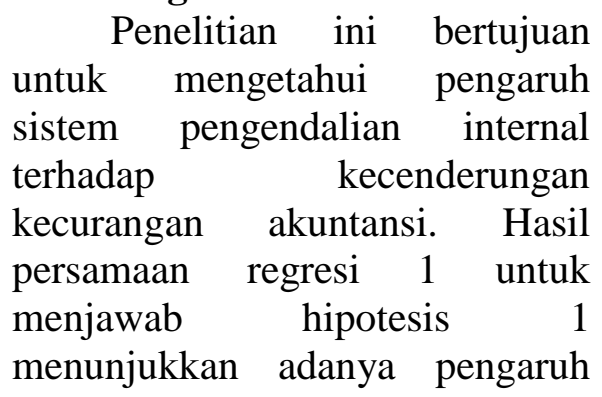

signifikan sistem pengendalian internal terhadap kecenderungan kecurangan akuntansi dengan tingkat signifikansi di bawah 0,05. Berdasarkan hasil pengujian hipotesis, sistem pengendalian internal diketahui thitung $(3,020)$ $>$ t tabel (2.060) dan $\operatorname{Sig}(0,006)<$ 0,05 . Hal ini menunjukkan bahwa hipotesis 1 di terima, artinya sistem pengendalian internal memiliki pengaruh positif terhadap kecenderungan kecurangan akuntansi

Dari hasil penelitian ini mengindikasikan bahwa hasil uji empiris penelitian ini sesuai dengan analisis di dalam teori atribusi dan teori agensi. Teori atribusi menjelaskan tentang perilaku seseorang terhadap peristiwa di sekitarnya dan mengetahui alasan-alasan melakukan perilaku seperti itu. Teori Atribusi yang dikemukakan oleh Robbins (2006) menjelaskan 
perilaku seseorang yang disebabkan oleh faktor internal. Perilaku yang disebabkan oleh faktor internal adalah perilaku yang diyakini berada di bawah kendali atau berasal dari dalam diri individu seperti ciri kepribadian, motivasi atau kemampuan. Jadi, jika faktor internal memberikan pengaruh negatif terhadap seseorang maka ia akan melakukan perbuatan menyimpang atau kecurangan.

Teori agensi menjelaskan organisasi sebagai hubungan kontrak antara pengelola dan prinsipal yang sarat dengan berbagai kepentingan dari setiap pihak. Ketika kepentingan salah satu pihak terganggu kesempatannya untuk terpenuhi maka ada kemungkinan bagi mereka untuk berperilaku menyimpang. Oleh karenanya diperlukan struktur yang dapat membatasi perilaku pengelola salah satunya dalam bentuk pengendalian internal.

Temuan tersebut konsisten dengan hasil Efendi (2010), Rahmawati (2012), Pradnyani (2014) dan toyibatun (2009) yang menunjukan bahwa sistem pengendalian internal memiliki pengaruh positif terhadap terjadinya kecenderungan kecurangan akuntansi hal ini dikarenakan pengaruh lingkungan (sebagai salah satu komponen pengendalian internal) yang ditata terhadap usaha untuk menekan munculnya kecurangan akuntansi. Penelitian ini menyarankan agar lingkungan dikembangkan sedemikian rupa sehingga dapat menjadi petunjuk bagi perilaku yang diinginkan.

\section{Perilaku Tidak Etis dan} Kecenderungan Kecurangan Akuntansi

Berdasarkan hasil pengujian hipotesis, prilaku tidak etis diketahui t hitung $(3,128)>\mathrm{t}$ tabel (2.060) dan Sig $(0,004)<0,05$. Artinya, variabel prilaku tidak etis secara parsial memiliki pengaruh positif terhadap kecenderungan kecurangan akuntansi, atau dengan kata lain hipotesis (H2) diterima.

Dari hasil penelitian ini mengindikasikan bahwa hasil uji empiris penelitian ini sesuai dengan analisis di dalam teori atribusi dan teori agensi. Teori atribusi menjelaskan tentang perilaku seseorang terhadap peristiwa di sekitarnya dan mengetahui alasan-alasan melakukan perilaku seperti itu. Teori Atribusi menurut Ikhsan dan Ishak (2005) merupakan suatu proses untuk menginterpretasikan suatu peristiwa, alasan, atau sebab perilaku seseorang.

Teori Keagenan dilandasi oleh beberapa asumsi. Asumsiasumsi tersebut dibedakan menjadi tiga jenis, yakni asumsi tentang sifat manusia, asumsi keorganisasian, dan asumsi informasi. Perilaku tidak etis berpengaruh terhadap kecenderungan kecurangan akuntansi sesuai dengan Asumsi teori agency yaitu sifat manusia menekankan pada manusia yang memiliki sifat mementingkan diri sendiri (self interest), memiliki keterbatasan rasionalitas (bounded rasionality), dan tidak menyukai 
risiko (risk aversion), dengan adanya asumsi ini membuat seseorang berperilaku tidak etis sehingga melakukan kecurangan.

Hasil penelitian ini mendukung penelitian yang dilakukan oleh adelin (2009), toyibatun (2009), sustriana (2015) dan mustika (2016) yang menyatakan bahwa perilaku tidak etis berpengaruh positif terhadap terjadinya kecenderungan kecurangan akuntansi. Hal ini disebabkan semakin tinggi perilaku tidak etis yang dilakukan oleh seseorang dalam suatu instansi maka semakin tinggi pula kecenderungan kecurangan (fraud) yang terjadi. Hal ini disebabkan moralitas merupakan suatu hal yang mempengaruhi tindakan dan perilaku seorang individu. Moralitas yang buruk akan membuat individu cenderung berperilaku tidak etis. Dalam suatu organisasi atau instansi, perilaku atasan, dan lingkungan kerja merupakan hal penting yang dapat mempengaruhi tindakan yang diambil oleh setiap pegawai. Dengan demikian semakin karyawan melakukan tindakan atau perilaku yang tidak etis maka akan semakin tinggi juga kecenderungan kecurangan (fraud) yang dilakukan karyawan maupun manajemen yang berada di dalamnya.

\section{Moralitas}

\section{danKecenderungan \\ Kecurangan Akuntansi}

Berdasarkan hasil pengujian hipotesis, moralitas manajemen diketahui t hitung $(4,134)>\mathrm{t}$ tabel (2.060) dan Sig $(0,000)<0,05$. Artinya, variabel moralitas

\begin{abstract}
manajemen secara parsial memiliki pengaruh yang signifikan terhadap kecenderungan kecurangan akuntansi , atau dengan kata lain hipotesis (4) diterima.

Hasil yang didapat sesuai dengan teori tahapan perkembangan moral yang menjelaskan tentang ukuran dari tinggi rendahnya moral seseorang berdasarkan perkembangan penalaran moralnya. Manajemen dengan moralitas yang rendah akan memicu terjadinya perilaku menyimpang dan kecurangan dalam kinerjanya. Termasuk adanya perilaku tidak etis dari manajemen dan kecurangan akuntansi. Moralitas manajemen yang rendah dapat meningkatkan perilaku tidak etis dan kecurangan akuntansi yang dilakukan manajemen perusahaan.

Hasil penelitian ini mendukung penelitian yang dilakukan oleh Rahmawati (2012), bahwa moralitas manajemen berpengaruh positif terhadap kecenderungan kecurangan akuntansi, Semakin tinggi moralitas yang dimiliki tiap manajemen sangat berpengaruh terhadap terjadinya kecenderungan kecurangan akuntansi pada perusahaan.
\end{abstract}

\section{PENUTUP}

Kesimpulan

Penelitian ini secara umum bertujuan untuk menguji dampak sistem pengendalian internal, prilaku tidak etis, dan moralitas manajemen terhadap kecenderungan kecurangan akuntansi pada perusahaan developer yang berlokasi di Pekanbaru. 
Berdasarkan hasil penelitian dan pembahasan di bab-bab sebelumnya, maka terdapat beberapa kesimpulan.

1. Sistem pengendalian internal berpengaruh signifikan terhadap kecenderungan kecurangan akuntansi.

2. Perilaku Tidak Etis berpengaruh signifikan terhadap kecenderungan kecurangan akuntansi.

3. Moralitas Manajemen berpengaruh signifikan terhadap kecenderungan kecurangan akuntansi.

\section{Keterbatasan}

Penelitian ini masih jauh dari kesempurnaan dan masih terdapat keterbatasan-keterbatasan yang ada. Beberapa keterbatasan penelitian ini antara lain:

1. Hasil penelitian ini tidak dapat digeneralisasikan pada lembaga lembaga keuangan lainnya. Hal ini disebabkan kondisi di beberapa perusahaan berbeda satu sama lain. Tidak dilakukannya metode wawancara dalam penelitian, mengingat kesibukan dari pihak responden.

2. Responden meminta agar kuesioner ditinggalkan, sehingga peneliti tidak bisa mengendalikan jawaban responden. Oleh karena itu, jawaban yang diberikan oleh responden belum tentu menggambarkan keadaan sebenarnya.

3. Data penelitian hanya dilakukan pada pertanyaan yang sifatnya tertutup, sehingga peneliti tidak mendapat argumen secara langusng dan detail dari responden secara keseluruhan.

\section{Saran}

Berdasarkan beberapa keterbatasan peneltian yang telah diungkapkan, maka diberikan saran untuk peneliti selanjutnya, antara lain:

1. Penelitian berikutnya disarankan untuk menambahkan metode lain seperti wawancara secara langsung kepada masing-masing responden yang bersangkutan agar didapatnya jawaban dari para responden dengan kesungguhan dan keseriusan serta relevan dengan jawaban yang dituangkan responden dalam angket atau kuesionernya. Hal ini juga akan bermanfaat dalam meningkatkan keakuratan data yang dihasilkan dan kesesuaian dengan fakta yang ada.

2. Penelitian selanjutnya disarankan untuk meningkatkan jumlah responden agar didapatkan gambaran yang lebih nyata.

3. Penelitian selanjutnya dengan tema yang sama yaitu terkait dengan sistem pengendalian internal, prilaku tidak etis, dan moralitas manajemen. sebaiknya memperluas ruang lingkup penelitian dan menambah variable penelitiannya. 


\section{DAFTAR PUSTAKA}

Adelin,Vani, 2009. Pengaruh Sistem Pengendalian Internal, Ketaatan Aturan Akuntansi, Dan Perilaku tidak Etis Terhadap Kecenderungan Kecurangan Akuntansi. Skripsi Program Sarjana Ekonomi Universitas Negeri Padang.

Efendi. Rozi. 2010. Analisis faktorfaktor yang mempengaruhi kecenderungan terjadinya kecurangan Akuntansi. Skripsi Program Sarjana Universitas Islam Negeri Pekanbaru.

Frilia, Figna. 2015. Pengaruh asimetri informasi, sistem pengendalian intern, dan kesesuaian kompensasi terhadap kecenderungan kecurangan akuntansi (studi empiris pada bank swasta yang ada di pekanbaru). Jurnal Ekonomi dan ilmu sosial, VOL.2 NO. 3-5

Griffin, Ricky W dan Ebert, Ronald j. 2007. Binis. Edisi Kedelapan. Jakarta: Erlangga.

Ikhsan, Arfan dan Ishak, Muhammad. 2005. Akuntansi

Keperilakuan.Salemba Empat.Jakarta.

Kompas.com. 2014. Catat, Ini 10 Pengembang yang Kerap Diadukan Konsumen. http://multiparadigma.lectur e.ub.ac.id/files/2014/09/034. pdf Diakses 20 januari 2017.
Kusumastuti, Nur Ratri. 2012. "Analisis Faktor-Faktor yang Berpengaruh terhadap Kecenderungan

Kecurangan Akuntansi dengan Perilaku Tidak Etis Sebagai Variabel Intervening" (skripsi). Semarang: Unversitas Diponegoro.

Mustika, Sri Hastuti, Sucahyo Heriningsih. 2016.Analisis Faktor-faktor yang Mempengaruhi

Kecenderungan

Kecurangan(Fraud):

Persepsi Pegawai Dinas Kabupaten Way Kanan Lampung. $\quad$ Simposium Nasional Akuntansi XIX. Lampung.

Pradnyani, Niluh Putu Normadewi Abdi. 2014. Pengaruh kefektifan pengendalian internal, ketaatan aturan akuntansi. Dan asimetri informasi pada akuntabilitas organisasi dengan kecenderungan kecurangan akuntansi sebagai variabel intervening (Tesis). Program Pascasarjana Universitas Udayana. Denpasar.

Rahmawati, Ardina P. 2012. Analisis pengaruh faktor internal dan moralitas manajemen terhadap kecenderungan kecurangan akuntansi. Skripsi Program Sarjana Fakultas Ekonomika dan Bisnis Universitas Diponegoro

Robbins, Stephen. P. 2006. Perilaku Organisasi (Drs. Benjamin Molan), Edisi Bahasa 
Indonesia, PT. Intan Sejati, Klaten.

Satyawati, Wilma, F. 2014. “' Pengaruh Sistem Pengendalian Internal, Moralitas Manajemen, dan Kesesuaian Kompensasi terhadap kecenderungan kecurangan akuntansi (Studi Kasus Pada Dinas Pendapatan, Pengelolaan Keuangan dan Aset Daerah Istimewa Yogyakarta). Skripsi Program Sarjana Ekonomi Universitas Islam Indonesia.

Sustriana. 2015. Pengaruh Pengendalian Internal, Keataatan aturan akuntansi , sikap tidak Etis dan Tingkat Pengalaman Manajer terhadap Kecenderungan

Kecurangan Akuntansi. Skripsi Program Sarjana Universitas Islam Negeri Pekanbaru.

Thoyibatun, Siti. 2009.Faktor-faktor yang Berpengaruh terhadap Perilaku Tidak Etis dan Kecenderungan Kecurangan Akuntansi Serta Akibatnya terhadap Kinerja Organisasi”. Jurnal Ekonomi dan Keuangan ,Universitas Negeri Malang.

Tribun Timur. 2015. Hati - Hati Kasus Properti Terbanyak Kedua Setelah Perbankan. http://makassar.tribunnews.c om/2015/01/04/sekali-lagihati- hati-beli-properti-inimasalahnya.Diakses tanggal 24 januari 2017. 